УДК 347.9

DOI https://doi.org/10.32849/2663-5313/2020.6.03

Наталія Василина,

канд. юрид. наук, дочент,

доиент кафедри правосуддя

Київського начіонального університету імені Тараса Шевченка

\title{
Валерія Гансецька,
}

канд. юрид. наук,

науковий співробітник відділу міжнародного приватного права і порівняльного правознавства Науково-дослідного інституту приватного права і підприємництва імені академіка

Ф. Г. Бурчака Начіональної академї правових наук Украӥни

\section{ФОРМИ ВРЕГУЛЮВАННЯ ЦИВІЛЬНО-ПРАВОВИХ СПОРІВ: МІЖНАРОДНІ ТА НАЦІОНАЛЬНІ СТАНДАРТИ}

У статті досліджуються міжнародні стандарти, що використовуються у сфері врегулювання ицвільно-правових спорів. Авторами аналізуються нормативно-правові основи для формування системи альтернативного вирішення спорів в Україні на рівні міжнародно-правової регламентачії та начіонального законодавства. Проведено порівняльний аналіз норм міжнародно-правових актів, що стосуються визначення понять «медіаиія», «міні-суд», «мед-арб», «приватна судова система», «незалежне встановлення фактів», «примирення», «арбітраж», їх основних ознак, а також приниипів. Авторами акиентується увага на гармонізаиії вітчизняної правової системи з європейськими стандартами захисту прав та свобод людини, зокрема, шляхом застосування різних, як альтернативних, так і інших, форм урегулювання иивільно-правових спорів. Досліджено ефективність проведення процедури медіаиї̈, значення та сутність даного прочесу, роль медіатора у прийняті взаємовигідного для конфліктуючих сторін рішення. Надано загальну характеристику факторів, які позитивно впливатимуть на якість проведення медіачї та сприятимуть поширенню иієї проиедури. У статті автори виокремлюють завдання процедури медіації в иивільному судочинстві, порівнюють медіацію та судовий порядок вирішення иивільно-правових спорів. Зазначено, що невипадково медіачія як альтернативна форма врегулювання спорів розвинена у міжнародній практиці. Розкрито роль та значення таких форм урегулювання спору, як міні-суд та мед-арб, та проаналізовано доиільність запровадження їх в начіональне законодавство. Актуальним видається аналіз такої форми, як приватна судова система, що є новелою в практииі зарубіжних краӥн. Зазначено, що європейське співтовариство приділяє значну увагу медіачії як альтернативній формі вирішення спорів у різних сферах життя суспільства. Зроблено висновок про уривчастий та несистемний характер чинного законодавства у иій сфері, а також необхідність урахування міжнародних стандартів під час розробки та вдосконалення нащіонального законодавства, що регламентує процедуру врегулювання цивільно-правових спорів.

Ключові слова: міні-суд, примирення, медіація, арбітраж, приватна судова система, альтернативне вирішення спорів.

Постановка проблеми. Напрям європейської інтеграції, який вибрала Україна, зумовив потребу переосмислити національну правову систему з огляду на загальноприйняті європейські стандарти i, відповідно, створити потужну систему захисту прав та свобод людини. Відомо, що нині в Україні захист прав та свобод людини i громадянина здійснюється виключно юрисдикційними формами захисту, що, як відомо, не завжди є ефективним. Тому перед країною постала нагальна потреба переглянути всю наявну систему захисту прав людини та привести її до європейських стандартів, які виступають взірцем належного та справедливого захисту.

Нормативно визначена вітчизняна процедура формування системи захисту цивільних прав та інтересів сприяе підвищеному інтересу як вітчизняних, так і зарубіжних науковців до дослідження міжнародної практики вирішення цивільно-правових спорів.

Натепер судовий порядок урегулювання цивільно-правових спорів містить досить багатьох недоліків. Загальновідомими є проблеми надмірної завантаженості та коштовності судів, які недоступні для більшості громадян, що жодним чином не сприяе 
ефективному та якісному судовому розгляду справи.

Проте варто зазначити, що це зумовлено не так недоліком законодавства (хоча, беззаперечно, це важливо), як тим, що навіть у разі ухвалення законного та обгрунтованого рішення конфлікт все одно до кінця не вичерпується, завжди залишається незадоволена сторона. Як відомо, законність рішення ще не означає його справедливість.

Водночас висока ефективність застосування форм альтернативного врегулювання спорів не означає, що європейський досвід у цій сфері цілком позитивним буде для нашої правової системи.

Безумовно, в умовах сьогодення по всьому світі існує досить велика кількість процедур, що забезпечують урегулювання конфлікту без участі судді. Зважаючи на це, насамперед необхідним $€$ їх грунтовне дослідження $з$ метою виокремлення можливих переваг, з подальшим їх розвитком як окремого інституту в Україні.

На жаль, можна констатувати, що це питання натепер є мало дослідженим. Тому досвід щодо захисту цивільних прав у сфері альтернативного врегулювання цивільноправових спорів та перспективи можливого його запровадження у вітчизняній правовій системі є актуальними питаннями в умовах сучасності.

Аналіз останніх досліджень та публікацій. Попри зростання уваги науковців до зазначеної теми та наявність наукових публікацій таких вчених, як В. Балух, Н. Бондаренко-Зелінська, Т. Кисельова, В. Коссак, Д. Проценко, К. Сєргєєв та ін., присвячених концепції врегулювання цивільно-правових спорів в Україні, дослідження міжнародних стандартів у сфері врегулювання цивільноправових спорів потребує окремої уваги з боку науковців та практикуючих юристів.

Метою статті $є$ дослідження європейського досвіду врегулювання цивільноправових спорів та можливість запровадження позитивного досвіду в національне ॥ законодавство.

Виклад основного матеріалу. У багатьох європейських країнах на рівні законодавства встановлено обов'язкове застосування альтернативного врегулювання цивільно-правових спорів. У Франції суд зобов'язаний запропонувати сторонам врегулювати конфлікт за допомогою механізму альтернативного врегулювання спору, а в Англії, якщо сторона відмовилася від застосування медіації, суд має право накласти штраф [1, с. 11].

Серед наявних форм альтернативного врегулювання цивільно- правових спорів найбільш оптимальними формами вважаємо переговори, медіацію та арбітраж. Низка процедур, які є похідними від основних вищезазначених (мед-арб, незалежне встановлення обставин, приватна судова система тощо), $є$ новими для вітчизняних реалій, проте цілком виправдано можуть біти застосовані.

Зупинимося трохи детальніше на кожній із цих форм.

Так, арбітраж (arbitration) (в Україні третейське судочинство) як форма врегулювання спору за допомогою нейтральної особи (арбітра), який уповноважений ухвалити обов'язкове для сторін рішення, активно застосовується сьогодні у вітчизняній практиці.

У таких країнах, як Бельгія, Нідерланди, Франціія, країнах Латинської Америки, Індонезії тощо обов'язковість спорів, які повинні бути розглянуті арбітром, встановлено на законодавчому рівні.

У країнах англо-саксонської правової сім'ї (Англії, США тощо) коло справ, які підлягають розгляду в міжнародному комерційному арбітражі, встановлюється прецедентним правом. Винятками є спори, що перебувають у компетенції виключно державних судів [2, с. 216].

Така форма врегулювання цивільно-правового спору, як медіація (mediation), визначається як врегулювання спору за допомогою незалежної, нейтральної особи (посередника,) який сприяє сторонам у врегулюванні конфлікту, враховуючи інтереси обох сторін.

Медіація є досить популярною формою врегулювання спору в США. Так, будь-який спір у сфері бізнесу, політики чи сімейний не проходить без серйозного переговорного процесу [3, с. 46]. Основная роль медіатора - забезпечити контакт між сторонами конфлікту, допомогти їм сконцентрувати увагу на дійсно наявних аспектах спору i запропонувати варіанти вирішення проблеми [4, с. 363].

В Україні медіація застосовується порівняно недавно, а саме з 1994 року. 32004 року почали активно проводитись експерименти щодо використання медіації. Новацією $€$ нещодавно внесені зміни до ЦПК щодо врегулювання спору за участі судді, який, по суті, виступає як медіатор. Варто зазначити, що вітчизняний досвід застосування медіації виправдовує себе та доводить високу ефективність урегулювання спорів.

Медіація порівняно із судовою формою захисту містить низку переваг, що доводить iï ефективність у всьому світі. Особливо актуальною є медіація для врегулювання сімейних конфліктів, спорів, пов'язаних із виконанням договорів та трудових спорів. 
Позитивний досвід у сфері медіації $є$ також у таких країнах, як Чехія, Франція, Словаччина, Фінляндія та Австрія.

Так, у Чехії діє Служба апробації та медіації, що підпорядкована Міністерству юстиції. У Франції медіатори мають бути акредитовані прокурором, після чого можуть підписати контракт із Міністерством юстиції Франції щодо надання послуг медіації. В Австрії послуги медіації надають департамент Міністерства юстиції та Асоціація пробації і соціальної роботи [5]. У всіх країнах медіатори повинні мати професійну кваліфікацію в галузі права, соціальної роботи або психології.

Варто також наголосити на інших формах врегулювання цивільно-правових спорів, які є дещо новими для сучасного світу, проте вже активно запроваджуються у багатьох країнах.

Так, «мед-арб» (med-arb) поєднує у собі дві форми, а саме медіацію та арбітраж. Це форма врегулювання спору за допомогою посередника-арбітра, що у разі недосягнення сторонами згоди уповноважений прийняти обов'язкове для сторін рішення в порядку арбітражу (Франція, Німеччина, Швеція). Завдяки використанню медіації до початку арбітражного процесу сторони мають можливість особисто висловити свої думки і зауваження щодо суті спору під керівництвом кваліфікованого і досвідченого посередника.

«Мед-арб» є хорошим прикладом ефективності та гнучкості форм альтернативного врегулювання спорів, практичне застосування яких допомагає досягти найбільшого ефекту залежно від обставин конкретного спору і потреб сторін.

Приватна судова система (private court system) (або суддя «напрокат») активно застосовується в країнах прецедентного права, а також Швеції, Бельгії та Нідерландах. Полягає вона в тому, що для врегулювання спору залучаються судді, які пішли у відставку і які за досить високу плату мають повноваження примирити сторони та ухвалити обов'язкове для них рішення. Приватна судова система має дещо схожі ознаки з арбітражем, проте тут спір вирішує колишній професійний суддя, який має вже немалий досвід. Вважаємо таку форму врегулювання спору досить ефективною для вітчизняної правової системи

Варто зазначити, що деякі зарубіжні та вітчизняні науковці приватну судову систему називають «міні-суд» [6], проте тут не має схожості із класичною судовою процедурою. Тут вона дещо подібна до переговорів, де роль посередника виконує професійний суддя у відставці.
Започаткували приватну судову систему Американська арбітражна асоціація для використання в комерційних спорах [7]. Проте ця процедура ефективно застосовується і у вирішенні, наприклад, трудових спорів.

Незалежне встановлення фактів (neutral fact finding) передбачає врегулювання цивільно-правового спору за допомогою незалежного фахівця, який досліджує комплекс питань, вирішення яких потребує спеціальних знань. Це по суті експерт, який вивчає обставини справи й оцінює їх об'єктивну сторону [8].

В Україні окремі елементи цієї форми застосовуються у вирішенні правових спорів, які виникають під час судового розгляду справи: залучається експерт з питань права або експерт в окремих категоріях справ, які потребують особливих знань, наприклад із почеркознавства або лінгвістики.

\section{Висновки}

Україна перебуває лише на початковому етапі становлення своєї власної правової моделі врегулювання цивільно-правових спорів. Проаналізовані форми, що активно застосовуються в багатьох європейських країнах, цілком можуть застосовуватися в Україні для більш гнучкого та ефективного захисту цивільних прав та інтересів за умови створення якісного законодавчого підгрунтя.

Тому можна з упевненістю говорити про нагальну потребу щодо впровадження позитивного європейського досвіду та створення ефективного механізму захисту цивільних прав та інтересів людини.

\section{Список використаних джерел:}

1. Коссак В. Альтернативне вирішення спорів як спосіб захисту порушених прав. Перспективи застосування альтернативних способів вирішення спорів (ADR) в Украйні : матеріали Другого Львівського міжнародного форуму (Львів, 26-29 травня 2009 р.). Львів: Львівський державний інститут новітніх технологій та управління ім. В. Чорновола, 2009. $221 \mathrm{c.}$

2. Любченко Я.П. Підходи до визначення сфери альтернативних способів вирішення спорів. Державне будівниитво та місиеве самоврядування. 2014. Випуск 27. С. 214-226.

3. Носырева Е.Л. Конфиденциальность внесудебного урегулирования споров по законодательству США. Российская юстииия. 2000. № 12. С. 46.

4. Xavier A. Mediation is here to stay! Indian Yearbook of International Law and Policy. 2009. P. 363-378. URL: http://www.arbitrationindia. com/pdf/mediation_tostay.pdf (дата звернення: 15.05.2020).

5. Шинкар T.I. Особливості правового забезпечення медіації в деяких зарубіжних країнах: 
досвід для України. URL : http://sd-vp.info/2017/ osoblivosti-pravovogo-zabezpechennya-mediatsiyiv-deyakih-zarubizhnih-krayinah-dosvid-dlyaukrayini/ (дата звернення: 15.05.2020).

6. Бережна I. Сумна доля альтернативних методів вирішення спорів в Україні. URL http://blog.liga.net/user/berezhnaya/article/2073. aspх (дата звернення: 15.05.2020).
7. Сергеев К. Нормативные акты, регулирующие альтернативные формы разрешения конфликтов. URL : http://www.law.edu.ru/doc/document. asp?docID=1129448 (дата звернення: 15.05.2020).

8. Луганская областная группа медиации. Основные понятия к разделу «Альтернативное разрешение конфликтов». URL : http://w3.lg.ua/ lrmg/glosar_rk.htm (дата звернення: 15.05.2020).

Vasylyna Nataliia, Hansetska Valeriia. Forms of civil law dispute resolution: international and national standarts

The research paper is devoted to the international standards used in the sphere of civil law disputes settlement. The authors analyze the regulatory framework for the formation of an alternative dispute resolution system in Ukraine at the level of international legal regulation and national legislation. A comparative analysis of the norms of international legal acts related to the definition of mediation, mini courts, med-art, private judicial system, independent fact-finding, reconciliation, arbitration, their main features and principles is conducted. The authors consider the problems and prospects of ensuring the compliance of the national legal system of Ukraine with the standards of the European community and the creation of an effective mechanism to protect human and civil rights and freedoms through the introduction of various forms of settlement of civil disputes. The general characteristic of the factors, positively influencing the quality of mediation application and facilitating the spread of this procedure is given. In the research paper, the authors highlight the problems of mediation procedure in civil proceedings, compare mediation and the judicial procedure for resolving civil disputes. It is specified that it is not accidental that mediation as an alternative form of dispute resolution is developed in international practice. The role and significance of such forms of dispute resolution of mini courts and medical art is disclosed and the expediency of their introduction into the national legislation is analyzed. The analysis of such form as private judicial system is a novelty in the practice of foreign countries. It is noted that the European community pays considerable attention to mediation as an alternative form of dispute resolution in various spheres of society. The conclusion was made about the jerky and non-systemic nature of the current legislation in this area, as well as the need to take into account international standards in the development and improvement of national legislation governing the procedure for resolving civil disputes.

Key words: mini-court, conciliation, mediation, arbitration, private court system, alternative dispute resolution. 